\title{
Márta Asztalos
}

\section{Barthelme's Twisted Fathering}

\section{On Donald Barthelme, The Dead Father}

\begin{abstract}
This paper approaches Donald Barthelme's The Dead Father along the dual, paradoxical, and seemingly mutually exclusive terms of quest and anti-quest, murder and rescue, life and death. Its objective is to show how these antonyms exist inseparably and interwoven in the novel, successfully resisting logically coherent binary orders. The master trope of the analysis is chiasmus, the trope of deception, which seems to open a fruitful and "untrodden" path for reading the novel. The first half of the essay examines the chiasmus taking place on the thematic level of the novel, in the power relations between Thomas and the Dead Father and the possible twists of this twisted trope. The second half examines this chiastic inversion of power relations as an ironic inversion, as a reversed Oedipal situation and tries to read the interplay of psychoanalytic theory and Barthelme's novel in terms of irony, ironical inversion, and parody.
\end{abstract}

Readers' attitudes towards Donald Barthelme's works are truly diverse, but usually they either hate or adore them: it seems that no real middle path exists. As Richard F. Patteson points out in his introduction to one of the essay collections on the writer, the same phenomenon can be detected in scholarly circles as well: "From the beginning, his fiction has stimulated differences of opinion." Of course, these differences manifest themselves not only in utterly positive or negative critical attitudes towards the writer's experimentalism, though, the groups of dissenters and admirers can be detected quite clearly. Critics have passionate debates where to place him. There are many critics $^{2}$ who treat him as a realist writer and claim that there is "nothing surrealist about him, his dislocations are real, his material quite actual,"3 while, opposing this view, there is a group of critics, considerable in size, who regard

1. Richard F. Patteson, "Introduction," in Critical Essays on Donald Barthelme, ed. Richard F. Patteson (New York: G. K. Hall, 1992), 5-21, p. 6.

2. William H. Gass, Mary Robertson, or Richard Schickel, just to name a few.

3. William H. Gass, "The Leading Edge of the Trash Phenomenon," New York Review of Books (25 April 1968), p. 5.

The AnaChronisT 12 (2006): 198-219 ISSN 1219-2589 
Donald Barthelme as a surrealist artist. 4 Larry McCaffery praises "the inward, metafictional quality of his writing," 5 while Charles Molesworth examines him as a "parodist, a special sort of ironist." 6 As we can see, the "absence of ... center" agreement is not only one of the main characteristics of Barthelme's own works, but extends over the critical and theoretical reflections on his writings as well.

Barthelme's short novel, The Dead Father that I intend to focus on in the following few pages, created an even wider schism in the critical and readerly audience. In 1975, when the novel appeared, "the Barthelme opposition, though small in number ... gathered up a head of steam" and "Barthelme criticism hit rock bottom." Hilton Kramer in his review in Commentary reduces The Dead Father into a "simple fantasy of filial revenge" and claims "the Barthelme followers" to be only critics, professors and literary editors. Robert Con Davis shares this view and states that "only specialized knowledge (a critical awareness) of the English tradition and its underlying structures can navigate" 9 a book of such complexity. This complexity or "impurity" arises from the fact that the text uses the methods of collage, pastiche and parody, makes use of bits and pieces of our culture and the novelistic tradition, creating allusions and innumerable interferences. Many of the reviewers and critics try to get closer to the meaning of the novel by attempting to solve the riddles of the allusions, and focus on the allegorical interpretation of the figure of the Dead Father. Quite a number of them produce long lists of possible solutions, trying to make sure that they do not leave out even the most farfetched ideas. Lance Olsen reads the figure of the Dead Father as "an omnipresent authority and a dismembered god, omnipotent and finally impotent, Orpheus, Zeus, Prometheus, Oedipus, Lear, the Fisher King."10 Olsen's list of allegories is only out-

4. John Barth categorizes his style as "urbane and urban semi-Surrealism" (John Barth, “Thinking Man's Minimalist: Honoring Barthelme," The New York Times Book Review [3 Sept 1989], p. 9).

5. Patteson, p. 6.

6. Charles F. Molesworth, Donald Barthelme's Fiction: The Ironist Saved from Drowning (Columbia: University of Missouri Press, 1982), p. 8.

7. Patteson, p. 10.

8. Patteson, p. 11.

9. Robert Con Davis, "Post-Modern Paternity: Donald Barthelme's The Dead Father," in Critical Essays on Donald Barthelme, ed. Richard F. Patteson (New York: G. K. Hall, 1992), 185-195, p. 194.

10. Lance Olsen, "Linguistic Pratfalls in Barthelme," South Atlantic Review 51.4 (November 1986) 69-77. Online. Gale Database. Contemporary Literary Criticism. Capital Comm Coll Lib, Hartford, CT. 22 March 2005. 
numbered by Dedria Bryfonski and Phyllis Carmel Mendelson, who provide an even longer "litany." Richard Todd aims to formulate a hierarchy of allegories by trying to put them in order according to their relevance. "He is God first of all. God as a father. And father as God. After that he is what you will: the Novel, Western Culture, Truth, Duty, Honor, Country."11

Opposing the previously mentioned group of critics, there are a number of scholars who claim that "such an allegorical interpretation, though not invalid, imposes a logic upon the text that distorts or neglects its literal development. ${ }^{12}$ These critics ${ }^{13}$ see the character of the Dead Father rather as an "open metaphor"14 or as a "complex symbol" whose different parts are to be taken as "emblems of paternity." 15 Walsh goes as far as stating that "the idea of fatherhood is a more fundamental unifying principle in The Dead Father than any abstract allegorical formulation."16

I should say that I mainly share Walsh's view and think that these, in certain cases farfetched, allegorical interpretations can be misleading to such an extent that they divert our attention from the key mechanisms of the text itself. They sidetrack and lead us into the depth of a vast and impenetrable forest of literary figures where it is almost impossible to "see the wood from the trees." In my opinion this "depth" of allegorical meaning can be a trap for the reader - one of the ways the novel makes fun of all too serious-minded "fathering." Therefore the critic or reader has to disengage the function of the brain that detects and decodes the possible allegorical and archetypal links "hidden" in the text, which in case of other literary works may prove so useful in interpretation. This situation is different, as the novel is so overloaded with possible allusive links: "the Dead Father as mythic father archetype is so sys-

11. Richard Todd, “Daddy, You're Perfectly Swell!” in Patteson, 44-46, p. 45. For further allegorical interpretations of the Dead Father read Neil Schmitz, "Barthelme's Life with Father"; Carl D. Malmgren, "Exhumation: The Dead Father" (the part entitled: Examining the Corpse); Michael Zeitlin, "Father Murder and Father-Rescue: The Post-Freudean Allegories of Donald Barthelme"; Régis Durand, "On the Pertinaciousness of the Father, the Son, and the Subject: The Case of Donald Barthelme.” Although not all of these essays focus on allegorical interpretations, quite a number of interesting ideas can be found in them.

12. Richard Walsh, "The Dead Father: Innovative Forms, Eternal Themes," in Patteson $173-84$, p. 175 .

13. Among many others: Richard Walsh and Robert Con Davis.

14. Walsh, p. 175 .

15. Con Davis, p. 186.

16. Walsh, p. 174 . 
tematically over-determined" 17 that it can be connected to almost every piece of art written up to this point. I agree with Robert Con Davis, who states that "Barthelme's novel forces one to rediscover how to read a novel, as the first lines ... show this novel's resistance to any simple interpretation."18

In my paper I will try to evade this pitfall, which offers itself too willingly, and aim to read the novel along the dual, paradoxical and seemingly mutually exclusive terms of quest and/versus anti-quest, murder and/versus rescue, life and/versus death. My objective is to show how these antonyms exist together inseparably and interwoven in the novel, successfully resisting logically coherent binary orders.

This characteristic of the text is apparent from the very first pages. When somebody starts reading the book he/she is almost immediately presented ${ }^{19}$ with the first, apparently unsolvable dilemma of the novel: the ambiguous existence of the Dead Father: "Dead, but still with us, still with us, but dead." 20 This sentence could be chosen as a motto for the novel, as it reveals so many things not only about the character of the Dead Father but about the signifying mechanisms of the novel as well.

\section{Quest and/versus Anti-Quest}

Barthelme's novel, on the surface, follows the traditional, teleological, linear structure of the quest narrative. The Dead Father and nineteen of his sons plus Julie set out in search of the Golden Fleece, which is expected to invigorate and rejuvenate the Dead Father. "When we are there, and when I wrap myself in its warm yellowness, then I will be young again .... I shall once more be wiry.... When I embrace or am embraced in its damned fine luster, the Dead Father said, all this will seem worthwhile." "When I douse myself in its great yellow electricity ... then I will be revivified." This level, or as Carl D. Malmgren puts it, the macrotext of the novel is a pastiche/parodic version of one of the most traditional literary plot types, in opposition to the majority of Barthelme's other works, in which not a single element of a target-oriented structure is spared. The Dead Father and the "little band of brothers" (9; 35), as the Dead Father knows them, are heading to acquire an object of desire, a Lacanian objet petit $a$, the mythical object of the Golden Fleece.

17. Malmgren.

18. Con Davis, p. 185.

19. On the very first page of the novel.

20. All parenthesized references are to the following edition: Donald Barthelme, The Dead Father (New York: Penguin Books, 1975). 
The actual goal of the "quest" is revealed only step by step to the Dead Father and the reader. The true intention of the brothers, especially Thomas's, is to get rid of the Dead Father. Although their plan is foreshadowed in some parts of the book, ${ }^{21}$ it is spelled out explicitly only in the very last chapter.

You are to get into the hole, said Thomas.

Get into the hole?

Lie down in the hole.

And then you'll cover me up?

The bulldozers are just over the hill, Thomas said, waiting.

You'll bury me alive?

You're not alive, Thomas said, remember?

Considering this final information, we can state that this level of their "mission" can be interpreted as an anti-Quest, for their real intention is not to acquire an object of desire but to get rid of "an Object Of Loathing,"22 an abject in the psychoanalytical sense. Or, from another point of view, they endeavour not to rejuvenate and rescue the Dead Father, but to murder him. At this point the two activities (to rejuvenate or to murder) seem to be two mutually exclusive possibilities, two goals in the minds of two parties of characters, and two simultaneous story patterns.

Examining the "Corpse of The Dead Father," Carl D. Malmgren states that as a result of the above mentioned inversion that takes place on the level of the plot the master trope for the text is chiasmus. He goes so far as positing that as a consequence of these opposing forces inside the narrative "the plot effectively cancels itself out.” Despite the fact that the chiastic inversion pointed out by Malmgren is not a chiasmus in the true sense of the word, I am inclined to think that identifying chiasmus as the master trope of the narrative is highly relevant (as we shall see in the forthcoming part of the essay). Yet, instead of short-circuiting the idea with coming to the conclusion that it is nothing else but "a crossing-out, an elimination," ${ }^{23}$ we can go much further following this line, dissecting "Corpse of The Dead Father" in the hope of reaching a deeper understanding of the novel.

First, let us examine further the Quest and anti-Quest doubles, having a closer look at the chi drawn by Malmgren. The novel retains its teleological structure till the

21. Thomas's story about the Great Father Serpent in chapter 6, an intuition of the Dead Father in chapter 19: "You are killing me" (p. 158), the presentation of the will in chapter 20, which the Dead Father is supposed to sign (p. 162).

22. Malmgren.

23. Malmgren. 
end, as the alliance reaches the targeted place of their mission, where the two lines converge, the two sides of the chi join, the Quest and anti-Quest meet (which have never been that different from each other). In the final chapter of the novel it is revealed that this Quest has always already been an anti-Quest as well, for the object of the quest, the desired Golden Fleece exists only "[i]n a sense" (73). It is nothing else but Julie's golden pubic hair, which has been within a hand's reach during the whole journey (but not for the Dead Father).

Julie lifted her skirt.

Quite golden, said the Dead Father. Quite ample. That's it?...

He moved to touch it.

No, said Thomas.

No, said Julie.

I'm not even to touch it?

No.

Even his "last request," to place his hand on it just once, is denied, and is declared to be "[u]nseemly" by Thomas (175). With this prohibition the degradation and the deprivation of the Dead Father of his authority, which have been taking place throughout the whole journey, culminates. He is degraded to the level of a child, whereas Thomas is raised to the highest point of his power - he is able to exercise the ultimate power of the Father, the Lacanian "non du père." The roles interchange: the Dead Father becomes an obedient "child/son," while the son, Thomas is transformed into an omnipotent "father-figure," who can do whatever he pleases, "can place his hand on the Fleece" signalling his power over everything. Both the Dead Father and the reader have been fooled and lured into a trap and we (the readers) have no other choice than to follow the Dead Father's example and pretend that we "knew all along" (176). But before we run too far ahead in our story, let us examine the whole process of role-changing.

\section{The chiasmic reversal of power relations}

The novel opens with a tableau in which the Dead Father's huge body is presented to us in detail. Although the description is quite matter-of-fact, it is constantly flirting with and skirting the tone of a heroic epic narrative. ${ }^{24}$ It is modelled on an epic enu-

24. Richard Walsh also mentions this characteristic of the very first, not-numbered chapter of the novel in his essay entitled "The Dead Father: Innovative Forms, Eternal Themes" (p. 175). 
meration, as all the noble and heroic attributes of the Dead Father are listed here. "Broad and noble. And serene, of course ... Jawline compares favorably to a rock formation. Imposing, rugged, all that" (3). According to Richard Walsh this first, italicised part of the novel can also be read as "a sort of protasis," as "it stands in relation to the rest of the text as the condition upon which its action is predicated." 25 The elevated and sonorous style of the narrative is debunked from time to time, for unfitting facts and details are inserted in the text as "verbal banana peels" and "they undermine the self-confident syntax." 26 "The full red lips drawn back in a slight rictus, slight but not unpleasant rictus, disclosing a bit of mackerel salad lodged between two of the stained four" (3). Not only does this very first section of the text introduce to us the figure of the Dead Father and his might, but it also establishes the power relations between him and his sons, especially Thomas (though we have not even met him at this point). "He controls the hussars. Controls the rise, fall, and flutter of the market. Controls what Thomas is thinking, what Thomas has always thought, what Thomas will ever think, with exceptions" (4; my emphasis). The last two words of the previous sentence can be interpreted as "verbal and structural banana peels" making use of and developing further Olsen's imaginative phrasing. Not only do they show us the "demythifying" dynamics of the novel at work, but they foreshadow the crisis and malfunction of patriarchal order, the decline of the Dead Father's authority.

When we first encounter Thomas in the first (numbered) chapter of the novel, he is the leader of the brothers who joined together to drag the Dead Father to the Golden Fleece/to his grave. We learn that he has just "thrown away the cap-andbells" (7), the humiliating orange fool's cap which signalled the sons' obedience and submission to the Father. Thus, the redistribution and takeover of power has already begun. From this moment on the power relations of the two characters change step by step. A "series of symbolic transfers of power ... occur at key stages of the novel." ${ }^{27}$ First, Thomas gets hold of the Dead Father's belt buckle.

May I try it on? ...

You may certainly try it on if you wish.

The Dead Father unbuckled the belt and handed it to Thomas.

Thomas buckled on the Dead Father's belt.

25. Walsh, p. 175.

26. Olsen.

27. Walsh, p. 181. 
I like it, he said. Yes, it looks well on me. The buckle. You may have the belt back, if you like.

My belt buckle! said the Dead Father.

Then he obtains his sword, his passport, and, finally, his keys $(79 ; 157 ; 170)$. By the end of the novel the Dead Father has been deprived of all the tokens of authority he had. The seizure of these phallic objects can be interpreted as symbolic castration, in the course of which Thomas deprives the Dead Father of "the signifier of signifiers," the phallus, which is "crucial in the distribution of power, authority and a speaking position, a kind of mark or badge of a social position." ${ }^{28}$ Moreover, Thomas starts acting like a symbolic father and exercising those tasks associated with Fatherhood over him: disciplining, prohibiting and articulating the non-du-père, the ultimate prohibition of the father, which hinders incest in the family. He acts like Freud's primal father who "prevented his sons from satisfying their directly sexual impulsions." 29 He never lets the Dead Father touch Julie and if he does so, he (Thomas) chastises him and forces him into abstinence and consequently into emotional ties with him. $3^{\circ}$

The Dead Father placed [Julie's] toe in his mouth.

Thomas rapped the Dead Father sharply in the forehead, across the cloth.

Toe fell from the mouth. The Dead Father clutched his forehead.

You have rapped the Father, he said between moans. Again. You should not rap the Father. You must not rap the Father. You cannot rap the Father. Striking the sacred and holy Father is an offense of the gravest nature. (55)

This quote shows us clearly that the Dead Father's no has no power, he cannot influence the course of events any more. He becomes a "Kafkaesque victim." ${ }^{11}$ Thomas has usurped his position and has absolute control over him. The power is exchanged and the symbolic roles are inverted.

It is clear that examining the power relations between the Dead Father and Thomas we come across an even more evident chiastic inversion than Malmgren did,

28. Elizabeth Grosz, Jacques Lacan, a Feminist Introduction (London: Routlege, 1991), pp. $121 ; 125$.

29. Sigmund Freud, "The Group and the Primal Horde," in The Standard Edition of the Complete Psychological Works of Sigmund Freud 18 (London: Vintage, 2001), 163-75, p. 124.

30. Freud, "The Group," p. 124.

31. Walsh, p. 180. 
studying the motives of Quest and anti Quest in the novel. It seems so obvious and clear that the reader starts to suspect, rightly. Furthermore, the scruple is inscribed into the text, as a twist that debunks the teleological structure of the (anti-)quest and does not let any totalising, coherent interpretation be imposed on the text, not even the logic of the twist (X) itself. This twist is placed into the book within the book, into A Manual for Sons, where it is laid down what happens when a father dies (and as we all know this is the destiny of the Dead Father decided by his sons).

When a father dies, his fatherhood is returned to the All-Father, who is the sum of all dead fathers taken together. ... Fatherless now, you must deal with the memory of a father. Often that memory is more potent than the living presence of a father, is an inner voice commanding, haranguing, yes-ing and no-ing ..., governing your every, your slightest movement, mental or physical. At what point do you become yourself? Never, wholly, you are always partly him.

A Manual for Sons overwrites the pattern of the story at the point when the reader has taken a glimpse at the intrigue behind the mission (the cabal behind the cable), the anti-Quest behind the Quest. This happens at the very moment when the reader starts to get his/her bearing in the novel, when s/he begins to trust the teleological structure and feels proud of himself/herself that $\mathrm{s} /$ he has some notion about the end. So, at the very point when the reader starts acting like an all-knowing "father," being positive that s/he holds the play of signification in his hands, his authority is shaken, his "fatherly" interpretation is "castrated." The Manual seems to disclose pieces of crucial information that cause a sudden turn in fortunes and it

32. Of course, these thoughts ring a bell to those of us who are familiar with Freudian and Lacanian psychoanalysis, not accidentally. One of the underlying discourses that Barthelme made us conscious of while making this novel is psychoanalytic theory. Régis Durand examining the Father, the Son, and the Subject in Donald Barthelme's works goes as far as stating that, thoroughly familiar with the catchwords of psychoanalysis, Barthelme "is determined to beat it at its own game" (Régis Durand, "On the Pertinaciousness of the Father, the Son, and the Subject: The Case of Donald Barthelme," in Critical Angles: European Views on Contemporary American Literature, ed. Mark Chénetier [Carbondale: Southern Illinois University Press, 1986], 153-63, p. 163). I think that this statement of Durand's is not well-considered and has no real foundation in his essay. In my opinion, The Dead Father is not only a postmodern but a post-Freudian text as well, and Barthelme uses the theories of Lacan and Freud (similarly to other literary texts and elements of popular culture) as raw materials from which he can build up his collage. 
projects a clear vision of the future, utterly different from the one the reader has expected. This information seems to give a further twist to our already twisted and twisting structure.

But before we put our trust in this Manual, let us examine the source where it comes from. It is brought to Julie and Thomas by its translator:33 Peter Scatterpatter, who gives it to them as a present which "[m]ight be of some use to [them]. On the other hand, might not" (108). The name of the presenter might carry some information about the source or the intentions of the Manual itself (on the other hand, might not). Let us examine the surname (Scatterpatter) a bit closer. The second part of the compound being of similar sound and meaning as the words: chatter, tattle, prattle can give us the notion that the whole text is nonsense, that reading it is a waste of time and energy. On the other hand, "to scatter patter" can mean to spread deceitful information ${ }^{34}$, so the intention of a man with such a name can be to diffuse misleading knowledge, to lead Julie and Thomas astray. So the Manual can be some means of deception, which aims at hindering the accomplishment of the (anti)-Quest. The very last chapter of it seems to support this idea, as it tries to dissuade the reader (Julie and Thomas) from committing patricide, "the principal and primal crime of humanity as well as of the individual": 35

Patricide is a bad idea, first, because it is contrary to law and custom and second because it proves, beyond a doubt, that the father's every fluted accusation against you was correct: you are a thoroughly bad individual, a patricide!" ... It is not necessary to slay your father, time will slay him, that is a virtual certainty. Your true task lies elsewhere. ... You must become your father, but a paler, weaker version of him. If your father was a captain in Battery D, then content yourself with a corporalship in the same battery.

33. Who translated the book from English into English (cf. Barthelme, p. 108).

34. The expression 'patter' is used when we refer to the jabber/double Dutch of a conjurer. Oxford Advanced Learner's Dictionary gives the following definition: "the rapid talk of a person telling jokes, performing tricks, selling sth, etc., intended to entertain, distract one's attention. .." (p. 850).

35. Sigmund Freud, "Dostoevsky and Parricide," in The Standard Edition 21 (London: Vintage, 2001), 173-96, p. 183. Régis Durand supports this reading of the Manual. He states that "the Manual for Sons" makes for an acceptance of, a compromise with, the unshakeable facts of fatherhood. Instead of the old Oedipal strategies of conflict or parricide it suggests avoidance, playing down the whole question" (p. 163). 
The manual gives clear-cut orders and instructions, and the tone of the narrator is highly paternalistic and stern. Furthermore, it protects the position of the father by pointing out that a son can never, should never, must never become a father in the fullest sense of the word. If the reader is attentive enough, these thoughts can sound familiar as they (or a slightly different version of them) were pronounced by the Dead Father in chapter five: "A son can never, in the fullest sense, become a father. Some amount of amateur effort is possible. A son may after honest endeavor produce what some people might call, technically, children. But he remains a son. In the fullest sense" (33). These facts indicate that The Manual for Sons may be a supporting pillar of Fatherhood and patriarchal authority (though, at first sight it seems to be aiming at the opposite direction).

On the other hand, the similarity of the two words patter and pattern may not be accidental. ${ }^{6}$ Pattern, meaning a special kind of order, can take us into the direction of reading the Manual as a book which spreads (scatters) knowledge about the order of the world or the system. This interpretation of the word is supported by one of the last sentences of the Manual as well: "You can see the pattern" (145). However, if we focus on another meaning of to scatter: to disperse, we get a different reading of the name and the Manual: It/He may aim at dispersing or upsetting the existing order, the order of the pat $(\mathrm{t}) e r$. With this last interpretation of the name we arrive at the point when the articulated objective of the Manual ("Fatherhood can be, if not conquered at least 'turned down' in this generation" [145]) and the meaning gathered from the name seem to correspond. Summing up and evaluating our results achieved up to this point in the domain of name-reading, we can establish that our (presumed) key-name and key signifier proves to "open" too many doors of possible interpretation, triggers too many opposing readings. It seems to be a "floating signifier," an unreliable "trope," one may say, as one talks about an unreliable narrator, which may seem to indicate the presence of an "unreliable translator" (or may not).

At this point the reader has two choices: either s/he accepts A Manual for Sons as a meta-narrative, which was written "over" the novel itself as a guidebook or a manual of rules not only for sons but for the reader as well, or s/he rejects and overlooks the information it comprises, following Julie's and Thomas's example. 37

36. The idea comes from a reading mistake, when reading the text for the first time, quite fast I misread the word, I mistook it for pattern. Moreover, when I checked the word in the dictionary I had to realize that pattern follows patter in the dictionary as well.

37. Julie "threw the book into the fire" (146). 
In the first case the reader concedes the truth of the manual and, henceforth, believes that in the "after last moment" of the novel (which is not presented to the reader deliberately) the Dead Father is to regain his power symbolically, following a post-Freudian and post-Lacanian logic, as the murder of the father according to Lacan is "the fruitful moment of debt through which the subject binds himself for life with the Law." 38 So, in this case "[t]he father [takes] up permanent residue in the son's soul, intertwining himself with the son's most intimate definition of self" 39 despite all the endeavor on the son's part to get rid of him. Following this line of thought we arrive at the conclusion that the Quest (to revivify the Dead Father with the help of the Golden Fleece) and the anti-Quest (to get rid of the Dead Father by "killing"40 him) run to the same endpoint, have the same result: the Dead Father regains his power over his sons, he is (physically and/or symbolically) fortified. Adopting the information laid down in A Manual for Sons as truth the reader starts to read on assuming that $\mathrm{s} /$ he has some kind of superior knowledge about the rules of the game, about the mechanisms of the novel and with a sense of certainty that s/he cannot be tricked.

If the reader chooses the second option and looks at A Manual for Sons as some trickery aiming at diverting the group of Thomas and himself/herself from their path by shaking their extant belief, s/he repudiates the information provided by the manual, does not let her/his reading strategies be subverted and reads on with some kind of superior knowledge and with a sense of certainty that $\mathrm{s} /$ he does not let anybody trick her/him. However, it may be worth being cautious with a book so doubtful about paternity.

In my opinion the Manual brings some kind of uncertainty into our interpretations, precisely because of the different possibilities of its credibility. If one takes it seriously, it gives a twist to the narrative, if one decides not to take it seriously, this very gesture will involve a twist. In either case, one cannot simply believe what $\mathrm{s} / \mathrm{he}$ sees, and interpretation becomes a "twisted" process, in which one has to re-evaluate one's opinions from time to time. Using the well-known Freudian metaphor, one may claim the mechanism of fort/da to be a peculiar feature of the game that the

38. Jacques Lacan, "On the Possible Treatment of Psychosis," in Écrits, trans. Alan Sheridan (New York: Norton, 1977), 179-221, p. 199.

39. Michael Zeitlin, "Father-Murder and Father-Rescue: The Post-Freudian Allegories of Donald Barthelme," in Contemporary Literature (Summer 1993) 182-203, p. 200.

40. As the reader must have already realized by this point the dichotomies of life and death have no real value in the world of the novel, they cannot be looked upon as fix points of the system. 
novel plays with the reader and his "fatherly" interpretative desires: from time to time the text robs the reader of the "fatherly" (serious, allegorical, totalizing) meanings that it has apparently offered previously, in a fashion very similar to the way Thomas takes everything back from the Dead Father that used to be his.

\section{Rescue and/versus Murder of the Father}

As Michael Zeitlin pointed out earlier, "the entire book is structured as an ambiguous rescue / murder of the father." 41 As we have seen, if we take seriously the "mockpsychoanalytic" principles of The Manual, we can draw the conclusion that it makes no difference whether we "murder" or "rescue" the Father because we carry out the truest or ultimate rescue by murdering him and setting up a permanent place for him in the ego.42

In the following part of my paper I aim to approach these two concepts (Fathermurder and Father-rescue) from another psychoanalytic standpoint, making use of the theories of Karl Abraham and other contemporaneous psychoanalysts. Freud was the first (1910) who examined and used the notion of "rescue phantasy" and pointed out the defiant meaning of such filial phantasies. 43 He claimed that governed by "a single wish to be his own father" 44 the son "forms the phantasy of rescuing his father from danger and saving his life; in this way he puts his account square with him." 45 This line of thought is familiar from the novel as well, as Barthelme worked this theory of Freud into the novel (in The Manual for Sons) creating a fine example of psychoanalytic intertextuality: "When you have rescued a father from whatever terrible threat menaces him, then you feel for a moment, that you are the father and he is not. For a moment. This is the only moment in your life you will ever feel this way" (139). So, in this sense, rescuing the father is the son's one and only possibility to take over his father's role and power, to break out from the role of the child, to undo or "murder" him as a father for a moment. Following this line of thought and bringing our murderous and rescuing lines together, we can state that one can symboli-

41. Zeitlin, p. 198.

42. Freud, "Dostoevsky," p. 184.

43. Whenever I quote or refer to the theories of Freud or Abraham I use the form "phantasy," as they refer to the phenomenon using this form.

44. Sigmund Freud, "A Special Type of Object Choice Made by Men," The Standard Edition

11 (London: Vintage, 2001), 163-75, p. 173.

45. Freud, "A Special Type of Object Choice," p. 172. 
cally murder or diminish his father by rescuing him and symbolically rescue and fortify his father by murdering him. Hence, we can come to the conclusion that the chiastic inversion or the twist is written into the psychoanalytic theory (of rescue and murder) itself. The novel, making use of psychoanalysis for its mythmaking, allegorises/ parodies it, giving the twist a further twist. Let us examine this latter twist later, in the following chapter.

Returning to our not truly abandoned line, the Freudian idea of rescue phantasy, we can find that Freud himself points out that the root of such a phantasy is nothing but defiance on the son's part, which is sustained by unconscious aggression. In "Mourning and Melancholia" he states that "hostile impulses against parents (a wish that they should die) are also integral constituents of neurosis." ${ }^{6}$ Following Freud's path and examining the wish-creations of neurotics, Karl Abraham goes as far as positing that the rescue phantasy contains an ambivalent meaning which includes the destruction of the father. 47 The unconscious rescue is synonymous with killing and "the transformation of an onslaught into a rescue is due to the stricter application of censorship." 48 Thus, rescue is nothing but a facade for the aggressive unconscious content of the phantasy. Richard Sterba, investigating aggression in the rescue fantasy, grasps the same problem from another side and states that "the content, 'rescuing,' expresses only a part of the complex fantasy, for the object to be rescued must first have been brought into the danger from which the producer of the fantasy is to save it." 49 In his reading endangering reflects the true intention of the producer of the phantasy and rescue is only self-protective.

Hence, having examined the underlying, unconscious content of a rescue phantasy we can come to the conclusion that the unconscious, emotive background for rescue and murder is the same. Putting it a bit more clearly (and, perhaps, harshly), according to psychoanalysis the difference between the two is only a matter of the effectiveness of censorship. So, from a psychoanalytic point of view the differentiation between the levels of Quest and anti-Quest in the novel loses its fundaments, throwing meaning into the abyss of the confusing twists of an ever-turning chiasmus, which makes all totalizing, "fatherly" interpretations impossible.

46. Sigmund Freud, "Mourning and Melancholia," in The Standard Edition 14 (London: Vintage, 2001), 237-6o, p. 240.

47. Karl Abraham, "Rescue and Murder of the Father in Neurotic Phantasies," The International Journal of Psychoanalysis 3 (1922) 467-74, p. 469.

48. Abraham, p 468.

49. Richard Sterba, "Aggression in the Rescue Fantasy," The Psychoanalytic Quarterly 9 (1940) 505-8, p. 505. 


\section{Irony, parody, the chi (and) sous rature}

For a critic writing (or rather trying to write) about Barthelme's The Dead Father it would be too much of a naivety to ignore the ironic discourse of the novel, to disregard its parodic quality, to take the whole novel, all the offered allegorical meanings and beautifully constructed parables (and the act of writing itself) too seriously. The text seems to possess a whole set of techniques that make such totalising approaches - so much cherished by Barthelme criticism ${ }^{50}$ - impossible. As Alan Wilde states: "his [Barthelme's] work refuses the epistemological quest for ultimates and absolutes." ${ }^{1}$ Hereinafter, I will try to illustrate and examine through some examples how these strategies function in the novel, the way the text works as an ironical discourse.

The Dead Father was slaying, in a grove of music and musicians. First he slew a harpist and then a performer upon the serpent and also a banger upon the rattle and also a blower of the Persian trumpet...

The Dead Father resting with his two hands on the hilt of his sword, which was planted in the red and steaming earth.

My anger said proudly.

Then the Dead Father sheathing his sword pulled from his trouser his ancient prick and pissed upon the dead artists, severally and together, to the best of his ability - four minutes, or one pint.

Impressive, said Julie, had they not been pure cardboard.

The passage starts with the portrayal of the "terrible scene" (11) in quite elevated style and an almost biblical tone. "The repetition of the "he slew" and "upon the" formula echoes the universe of the epic catalogues." ${ }^{2}$ The sonorous eulogy goes on without any fault for almost one page, though the logorrhea of the narrator implants

50. Quite a number of the critics who have interpreted Barthelme's novel up to this point walked into this trap deluding themselves with the hope that the meaning of the novel can be discovered, can be grasped in some kind of a totality through providing a bunch of allegorical readings. However, the impossibility of coincidence with the substance and by this, possibility of a synthesis and the experience of totality is inscribed in the nature of allegory itself. (Paul de Man, "The Rhetoric of Temporality," in Blindness and Insight: Essays in the Rhetoric of Contemporary Criticism [London: Routlege, 1989], 187-229, p. 207).

51. Alan Wilde, "Barthelme Unfair to Kirkegaard: Some Thoughts on Modern and Postmodern Irony," in Patteson, 100-124, p. 122.

52. Olsen. 
the feeling in the reader that something is brewing. The well-constructed narrative collapses with the introduction of the words: "prick," "pissed," which suddenly create an ironic distance from the heroism of the previous passage. Applying a stylistically contrastive, inverse expression, a counter-term instead of the locution which could meet the reader's expectations fostered by the previous passages, the text performs ironical inversion on the stylistic and semantic levels of the novel. "The dogma of lexical and tonal consistency collapses"53 through the novel's "heteroglossia," thus, the language contract which secures the father's authority is violated. The paternal function which is "ultimately a function in narrative structure ... which prohibits mere repetition and sequentiality" 54 is destroyed, the power of the father is annihilated. The Law, which is identical with the symbolic order of language55 is "inverted" by the irony of the text. Thus, taking seriously a discourse with such a respectable quantity of "linguistic illegality," 56 and reading the text as if it functioned according to "the rational economy of language associated with paternal authority" 57 would most likely be a naive mistake. On the other hand, Umberto Eco states that it is in the quality of irony to make it possible for one to take the post-modern game seriously without understanding it. "There's always someone who takes ironic discourse seriously." 58 However, in my opinion (and according to my experiences) the reader or the critic himself/herself might experience a "de Manian fall" engendering the dédoublement 59 of the self ${ }^{\circ}$ (and in our case of the reading technique) when s/he aspires to father a "serious reading" of the text. According to de Man, the falling of the subject and the laughter of him at himself falling generates the dédoublement, the reflective disjunction of the self, the birth of the "ironic, twofold self." The subject is split into "an empirical self that exists in a state of inauthenticity and a self that exists only in the form of language that asserts the knowledge of this inauthenticity." 61

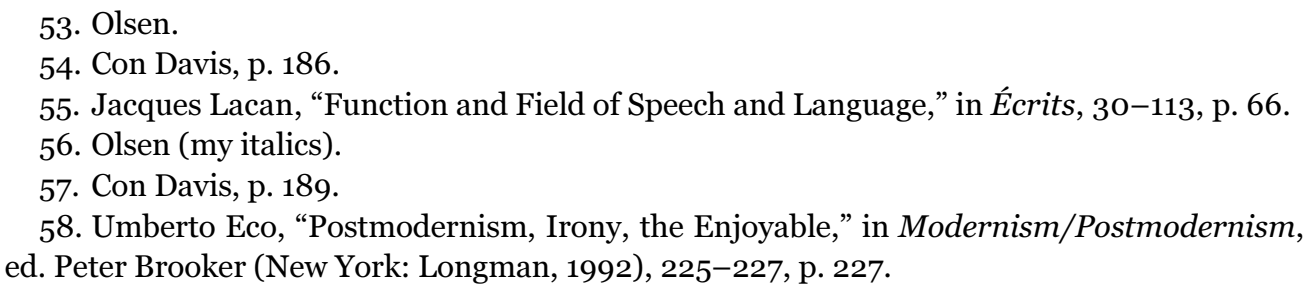

59 . "[T]he characteristic that sets apart a reflexive activity ... from the activity of the ordinary self caught in everyday concerns" (de Man, p. 212).

6o. De Man, pp. 212-13.

61. De Man, p. 214. 
An example of this fall can be observed in this essay in the part where I attempt to read the name of $A$ Manual's translator (Scatterpatter) by means of deconstructive close reading, which usually proves quite efficient in other cases. In the present instance, as we have already seen, the time-honoured method "fails" and the critic "falls," as our key signifier proves to be informative to such an extent that it becomes almost uninformative. Applying Paul de Man's theory of irony to the act of reading, we can state that "the element of falling introduces the specifically comical and ironical ingredient" to the reading process and shakes the reader out of his/her naivety. The critic/reader realizes the "mistaken, mystified assumption he was making about himself" and about the text. His failure or fall awakens the critic to realize the inauthenticity of his reading, moreover, every further attempt to return to his "neverfailing" method "asserts the knowledge of this inauthenticity" and mystification.62 Tamás Bényei talks about a highly similar (ironical) experience of the reader when he discusses the effect of ironical inversion:

They make the reader at least momentarily conscious of his interpretive desires and procedures, awakening him from a relatively blissful state of innocent reading into an awareness of what he's doing, into a knowledge of the preconditioned, programmed nature of his reading habits. Every time his expectations are frustrated by the ironical inversion of one or another of the well-known clichés, he has to make a choice between reading the inversion as a minor textual or narrative irregularity which, annoying as it may be, does not affect the generic cohesion and identity of the text (and thereby put off his exit from the innocent reading), or trying to eliminate his now painfully explicit and conscious generic expectations, on the assumption that the text he is reading follows a narrative pattern hitherto unknown to him. 63

According to Bényei, in case the reader chooses the second option he "will come up with a new reading strategy rooted in his frustrations" and when "the next discrep-

62. De Man, p. 214. However, the two reading strategies have to function hand in hand and give birth to a new strategy, as we have seen that a "serious" interpretation cannot stand the test of the ironic text, and a totally ironic reading would be nothing but madness, as "absolute irony is a consciousness of madness, itself the end of all consciousness"; and "[s]anity can exist only because we are willing to function within the conventions of duplicity and dissimilation" (pp. 215-16).

63. Tamás Bényei, "Ironic Parody or Parodistic Irony? Irony, Parody, Postmodernism and the Novel," Hungarian Journal of English and American Studies 1.1 (1995) 89-125, pp. 100-1. 
ancies appear, therefore, he is no longer the victim of the text's irony: he is - or he thinks he is - now an ironist himself." Let me remark here that the essence (and the irony) of irony lies in this interpolation, as at the very moment the reader thinks that he is an ironist himself, is he the farthest from that position, as he is taken in again by a mystification. To become a truly "ironic mind" the reader has to keep the state of dédoublement or "folie lucide" as irony is "the recurrence of a self-escalating act of consciousness." 64 Bényei also thematizes the trait of endlessness inherent in irony by stating that "irony tends to generate a kind of regressus ad infinitum in the reading process," which, becoming explicit, transforms the two-layered structure of irony into an endless spiral, and irony into a device engendering uncertainty. 65

Ironical/ironic inversions, which generate the failure of traditional interpretive processes, are characteristics of all parody. To put it in another way, parody is a "repetition with critical distance, which marks difference rather than similarity." 66 Hence, the interplay of psychoanalytic theory and Barthelme's novel may undoubtedly be described in terms of irony, ironical inversion and parody. ${ }^{67}$ Considering the chiastic inversion of power relations drawn up in the previous part of the essay, we can state that besides being an (excellent) example of chiasmus it is also an ironic inversion, as it is a reversed Oedipal situation, where the son bears the power, authority, and knowledge (of the plan), together with the mother's (Julie's) love and access to her body. Therefore, Barthelme's novel can be regarded as a parody or a parodistic rewriting of Freudian and Lacanian psychoanalysis: 68 "The fucked mother conceives, Julie said. The whelping is, after agonies I shall not describe, whelped. Than the dialogue begins. The father speaks to it. The 'it' in a paroxysm of not understanding. The 'it' whirling as in a centrifuge. Looking for something to tie to. Like a boat in a storm. What is there? The father" (77).

64. De Man, pp. 220; 216; 220.

65. Bényei, pp. 102; 103.

66. Linda Hutcheon, "Introduction," in The Theory of Parody (New York: Methuen, 1985), $1-29$, p. 6.

67. For further information on the relation of irony to parody or parody to irony, see Tamás Bényei, "Ironic Parody or Parodistic Irony?"

68. What would Freud say to this? To connect psychoanalytic theory and (its) parody on another level let me remark here that reading parody from the perspective of psychoanalysis (reversing the reversal) we can claim that, most surprisingly, Freud would possibly be highly pleased, as he states in one of his essays that "[c]aricature, parody and travesty ... are directed against people and objects which lay claim to authority and respect, which are in some sense 'sublime" " ("Jokes," p. 200). Could he ask for more? 
Chiasmus, irony and parody seem to display analogies not only in the text but on a more general level as well, since all of them are based on deception. "Chiasmi are the tropes of deception and of the (dis)tors/(t)ion of (the presence of) meaning." 69 "The rhetorical structure of irony ... is based on deception. ... Both parody and irony are deceptions that expose themselves as deceptions."7o

Examining the disruption of surfaces and the functioning of linguistic games in the text, Michael Zeitlin states that these verbal games and the playfulness of the text are nothing but "diversionary tactics," "ruses" which "transfer our attention from the underlying parricidal theme," from the "father's humiliation." 71 However, we should not forget that, being a parody, the underlying parricidal theme is itself a ruse, a deception. On the other hand, the reader can easily discern that the majority of (verbal) ironies in the text are directed against the figure of the Dead Father, of course, not accidentally. Now, let us have a look at some examples: "A bit left out, said the Dead Father. A bit. That is what I feel, at the moment. ... Excluded, said the Dead Father. It is because you are an old fart, Julie explained. Old farts don't get much" (10). The Dead Father's childish weeping is deconstructive in itself, as instead of positioning him as the bearer of authority, and power it casts a degrading light upon him, it defines him as a vulnerable, impotent creature. His childlike position becomes even more explicit if we consider that this dialogue takes place after Thomas and Julie return from the bushes, where she gave Thomas "a suck of the breasts." The situation bears close resemblance to an Oedipal triangle, though it is an inversed/subverted version of it: the excluded member who cannot possess the mother (Julie) is the Father, and the lucky one who can indulge himself is the son. Subversion takes place not only on the plot level but on a semantic level as well, as Julie answers to the Father's childlike whining with a vulgar snort. To provide another example, we can have a look at the following quotation as well, in which the Dead Father, to prove his virility, lists all the items he has fathered. "I fathered upon her in those nights the poker chip. The cash register, the juice extractor, the kazoo, the rubber pretzel. .." (36). The litany starts with a style evoking that of the Genesis but the enlisted offspring resemble rather the supply of a rummage sale. So, instead of proving his manhood and potency the list of these worthless junks symbolically castrates him. Thus, we might say that it is language itself that snatches and pulls down the

69. György Kalmár, “Az ördög írása: Thomas Hardy: Erdőlakók,” in Szöveg és vágy pszichoanalízis - irodalom - dekonstrukció (Budapest: Anonymus, 2002), 135-153, p. 150 (my translation).

70. Bényei, pp. 108-111.

71. Zeitlin, p. 192. 
figure of the father from the epic and heroic elevation, that performs the humiliation and castration of the father. Thus, we might say that the vehicles of "father-murder" or parricide are not the bulldozers in the text but (ironic) language itself, which turns against "the figure of the law."72

Nevertheless, parody has an effect working against the above seen "murder" of its object. We should take into consideration the fact that however parasitical parody73 may be, it also "inscribes the mocked conventions onto itself, thereby guaranteeing their continued existence." Or to put it another way, parody has a "potential power both to bury the dead ... and also to give it new life."74 Hence, the dead material remains, at least to some extent, alive, 75 it is "[d]ead, but still with us, still with us, but dead" (3). Thus, the textual world of The Dead Father is also the realm of irony and parody from the outset, in which the status of the incorporated materials (for example psychoanalytic theory) highly resemble that of the Dead Father. "Fragile, yet present" (67). They are deprived of their "organic" existence, their "authority," to attain a hollowed out subsistence, a meagre (non)existence, in which they duplicitously pretend to be alive ${ }^{7}$ only to be "reminded" that "you're not alive ... remember?" (175).

The dialectic of destruction and conservation which characterizes the relationship of parody and the parodied text or tradition may be described productively with the notion of the Derridean "sous rature" ("under erasure"), as the two phenomena seem to display some essential semblance. Derrida draws the idea of the concept from Heidegger, but he starts to use the notion in a slightly different way. Hereinafter, I will examine how the concept of parody can be brought into play with the two diverging though analogous notions of the "sous rature." Explaining Heidegger's concept, Derrida writes that "that mark of deletion is not ... a "merely negative symbol' .... That deletion is the final writing of an epoch. Under its strokes the presence of a transcendental signified is effaced while still remaining legible ... is destroyed while making visible the very idea of the sign." 77 "Since the word is inaccurate it is

72. Lacan, "Function," p. 67.

73. That, of course, "is by definition always ironical" (Bényei, p. 116).

74. Hutcheon, pp. 75; 101.

75. Bényei, p. 95.

76. Bényei, p. 94.

77. Jacques Derrida, Of Grammatology, trans. Gayatri Chakravorty Spivak (Baltimore: Johns Hopkins University Press, 1976), p. 23. 
crossed out. Since it is necessary it remains legible." 78 Thus, we might say that the condition of the word "under erasure" is, in a sense, analogous with that of the parodied text/tradition, as both of them are proclaimed to be inaccurate or exhausted and are destroyed in their metaphysical presence. On the other hand, both of them are necessary, hence they remain legible. The legibility of the parodied text is highly important in parody, as "parody is unable to function unless it ensures by textual means that the target text is properly recognized by the reader." 79 Moreover, as we have seen earlier, neither parodying a text, nor putting a word "under erasure" can be read merely as a negative act, the conservative force is always already there besides the subversive one.

The alteration of (self-)destruction and (self-)conservation/invention may also describe the parodic text's relation to itself, as "by parodying a tradition the parodie text inevitably becomes part of the parodied tradition ... [so] every parody is potentially a self-parody as well." ${ }^{\circ}$ Consequently, the parodic text's irony may probably be targeted against itself at some places ${ }^{81}$ (Julie's statement: "[Y]ou are perpetuating myths" [67] may refer to the novel itself as well), so the parodic text may also perform a "self-cancellation," it may also put itself "under erasure." Hereby, the chi of the chiastic inversion that we have drawn upon the novel, may also signal the chi of "sous rature" by which the novel cancels itself signalling "its evasiveness and reluctance to commit [it]self and be present." 82

\section{Conclusion}

As the psychoanalytic investigation of the novel shows, the paradoxical terms of quest and/versus anti-quest, murder and/versus rescue, life and/versus death, which can be kept apart in "normal" cases, are thoroughly intertwined in the novel. Moreover, if we rely on the (somewhat) inverse logic of psychoanalysis (according to which one can symbolically rescue and fortify his father by murdering him) we might

78. Gayatri Chakravorty Spivak, “Translator's Preface," in Jacques Derrida, Of Grammatology, ix-lxxxvii, p. xiv.

79. Bényei, p. 110 .

80. Bényei, p. 92.

81. By this statement we come close to what Margaret Rose claims, who "equates parody with self-reference" (Hutcheon, p. 20), merging the concepts of meta-fiction and parody.

82. Bényei, p. 109. Or the critic puts the novel "under erasure," signalling that she is still not a truly ironic mind, as she still has not managed to get rid of her longing for a totalizing reading. 
state that a slight modification of the much quoted sentence: "Dead, but/therefore still with us, still with us, but/therefore dead" can bring us closer to the understanding of the novel.

On the other hand, examining the novel as an ironic and parodic text and establishing that the novel's textual world is the realm of irony we need to have a look at these paradoxical pairs from another, ironic standpoint. The inverse mechanism of irony makes it impossible to treat these (or any other) concepts as fixed points which can stand in an invariable, stable position to other notions. The constant play of differentiation and conformation, which characterizes irony, makes the notions of paradox and analogy irrelevant in an ironic realm.

At this point the following question arises: Is the novel really as subversive and transgressive as the above-mentioned conclusions indicate or as critics like Thomas M. Leitch or William Stott claim? Is the novel able to live up to Thomas's manifestolike statement: "The family unit produces zombies, psychotics, and warps. ... In excess of what is needed" (78)? The parodic quality of the novel, its subsisting upon a well-established and well-known "tradition" seem to indicate that it is not. Moreover, Linda Hutcheon's argument that parody is "legalized though unofficial subversion" ${ }_{3}$ also seems to confirm that our suspicion is justified.

The parodic and ironic quality of the novel seem to give a twist (remaining loyal to our master trope) not only to our reading strategies but to our foregoing reading as well, and makes us reconsider the significance and relevance of it. In a sense the critic's only possible solution at this point is to put his/her reading "under erasure" as well, as it seems to be possible only this way to address a novel so much concerned with (self-)destruction and (self-)invention, with murder and rescue, with life and death. Writing criticism about such a twisting and twisted parodic text probably has to be also a constant self-cancellation and self-assertion, of affirmation and revocation, a constant revitalization and murder of one's fatherly interpretive habits.

83. Hutcheon, p. 75. 